\title{
A P-lekötődés és -szolgáltatás tanulmányozása tenyészedény-kísérletben
}

\author{
SÁRDI KATALIN \\ Veszprémi Egyetem Georgikon Mezőgazdaságtudományi Kar, Keszthely
}

\section{Bevezetés}

A talajba juttatott foszformütrágyák vízoldható formában lévő vegyületei többnyire rövid időn belül valamilyen kevésbé vagy nem felvehető formává alakulnak át. Ezt sok kísérleti eredmény igazolja, melyek arra is rámutatnak, hogy a folyamat intenzitása, tehát a P-megkötés (adszorpció) és -lekötődés (fixáció) mértéke a talajok tulajdonságainak függvénye (MENGEL, 1982).

A foszfor lekötődésében fö szerepet játszó talajtulajdonságokat számos kísérletben tanulmányozták és azt is kimutatták, hogy a jelenséget nagymértékben befolyásolja a talajok agyagásványainak mennyisége és minősége (PRATT et al., 1969; GALINDO et al., 1971 stb.).

A P- és K-mérleget tartamkísérletekben ugyancsak több szerző tanulmányozta (PRASAD \& SINHA, $1981 \mathrm{stb}$.)

A foszfor utóhatásának tanulmányozására különböző növényekkel végzett kísérletek eredményei rámutattak arra, hogy az egyes fajok között jelentős különbségek vannak abban, hogy milyen mértékben képesek felvenni a nehezebben oldódó foszfátokat, bár ez a tenyészidő hosszával együtt csökken. Az angolperje egyes növényeknél jobb hatásfokkal képes a mütrágyák utóhatásából származó foszfor felvételére (BARROW, 1980).

Korábbi kísérleteinkben az Országos Mütrágyázási Tartamkísérletekből (OMTK) származó talajokkal, angolperje jelzőnövénnyel tenyészedény-kísérletekben vizsgáltuk a különböző talajtípusok tápelemszolgáltató képességét. A kálium tápelemre kapott eredményeket több közleményben ismertettük (SÁRDI, 1993; SÁRDI \& DEBRECZENI, 1998).

A kísérletek során elvégzett vizsgálatok eredményei lehetőséget adtak a mütrágyával kijuttatott foszfor utóhatásának, valamint az oldhatósági viszonyok megváltozásának tanulmányozására is. A kísérleti eredmények további elemzésével arra a kérdésre is választ keresünk, hogy a foszfor lekötődése és az agyagásványok minősége között milyen kapcsolat mutatható ki. 
Kísérletünk e részében, a foszforvegyületek oldhatósági viszonyainak tanulmányozása során vizsgálatainkat az alábbi kérdések köré csoportosítottuk:

- Hogyan tudják a növények hasznosítani a tartamhatásból származó foszfort?

- Milyen a frissen adott foszfor hatása?

- Milyen mértékben képesek a talajok a foszfort biztosítani hosszabb időn át (az angolperje növedékei számára)?

- Milyen az egyes talajféleségeknél a P-adszorpció mértéke, ill. van-e -szolgáltatás?

\section{Anyag és módszer}

A tenyészedény-kísérletet az OMTK 9 kísérleti helyéről - a megfelelően kiválasztott parcellák talajából - az A/1920. számú kísérletből, a 20. évben vett talajmintákkal állítottuk be angolperje jelzőnövénnyel. Az $1 \mathrm{~kg}$ talajt tartalmazó tenyészedényekbe 1000 angolperje magot vetettünk CHAMINADE (1960) módszere alapján. A talajokat a vízkapacitás 100 \%-ára (vízátfolyásig) öntöztük.

A kísérleti helyek, ill. talajok föbb agroökológiai, talajtani, valamint agrokémiai jellemzőire itt nem térünk ki, azok a tartamkísérletek eredményeit ismertető „Trágyázási kutatások 1960-1990” címü könyvben (DEBRECZENI B. \& DEBRECZENI B-NÉ, 1994) megtalálhatók.

A 20 éven keresztül alkalmazott alapkezelések az NPK sorrendjében az alábbiak voltak: 000, 441 és 442, azaz trágyázatlan kontroll, valamint 200-200100, ill. 200-200-200 kg/ha N- $\mathrm{P}_{2} \mathrm{O}_{5}-\mathrm{K}_{2} \mathrm{O}$. Az egyes alapkezelésekre adott új kezelések az alábbiak voltak: $\mathrm{N}_{1}, \mathrm{~N}_{1} \mathrm{P}_{1}, \mathrm{~N}_{1} \mathrm{P}_{1} \mathrm{~K}_{1}, \mathrm{~N}_{1} \mathrm{P}_{1} \mathrm{~K}_{2}, \mathrm{~N}_{2} \mathrm{P}_{2}, \mathrm{~N}_{2} \mathrm{P}_{2} \mathrm{~K}_{1}, \mathrm{~N}_{2} \mathrm{P}_{2} \mathrm{~K}_{2}$. A 4 ismétlésben végzett kezelésekben kijuttatott $\mathrm{P}$-mennyiségek: $\mathrm{P}_{1}=200, \mathrm{P}_{2}=$ $400 \mathrm{mg} \mathrm{P}_{2} \mathrm{O}_{5} / \mathrm{kg}$.

$\mathrm{Az}$ angolperjét 5 alkalommal vágtuk. A vágások után meghatároztuk a növények szárazanyagtömegét, NPK-tartalmát és az edényenként felvett foszfor mennyiségét $\left(\mathrm{P}_{2} \mathrm{O}_{5} \mathrm{mg} /\right.$ edény). A felvett foszfor mennyiségét nem elemi foszforra vonatkoztatva adjuk meg, hogy a talajban lévő, $\mathrm{P}_{2} \mathrm{O}_{5}$-ben kifejezett értékekkel összevethetö legyen.

A foszfor tápelemforgalom tanulmányozására egy leegyszerüsített mérlegszámítást alkalmaztunk: a talajok kiindulási foszfor tartalmához (AL- $\mathrm{P}_{2} \mathrm{O}_{5}$ $\mathrm{mg} / \mathrm{kg}$ ) hozzáadtuk a kezelésekben alkalmazott foszfor mennyiségét, majd ebből levontuk a kísérlet végén mért mennyiséget $\left(\mathrm{AL}-\mathrm{P}_{2} \mathrm{O}_{5} \mathrm{mg} / \mathrm{kg}\right)$ és ezt összehasonlítottuk az angolperje által összesen felvett foszfor mennyiségével $\left(\mathrm{P}_{2} \mathrm{O}_{5}\right.$ $\mathrm{mg}$ /edény). Így kiszámítható volt, hogy az egyes talajokon és alapkezelésekben, valamint a frissen adott foszfor hatására a növények hozzá tudtak-e jutni az így nem mérhető P-formákhoz vagy a foszfor lekötődése volt-e jellemző az adott talajon.

A talajok föbb agrokémiai tulajdonságait, valamint a kísérlet kezdetekor mért AL-oldható P-mennyiségeket $\left(\mathrm{AL}-\mathrm{P}_{2} \mathrm{O}_{5} \mathrm{mg} / \mathrm{kg}\right)$ az 1. táblázat tartalmazza. 


\section{1. táblázat}

Az Országos Mütrágyázási Tartamkísérletek talajainak főbb agrokémiai mutatói és AL-oldható foszfortartalma ( $\left.\mathrm{AL}-\mathrm{P}_{2} \mathrm{O}_{5} \mathrm{mg} / \mathrm{kg}\right)$ a kiválasztott kezelésekben

\begin{tabular}{|c|c|c|c|c|c|c|c|}
\hline \multirow{2}{*}{\multicolumn{2}{|c|}{$\begin{array}{c}\text { (1) } \\
\text { Kísérleti hely }\end{array}$}} & \multirow{3}{*}{$\begin{array}{c}\mathbf{p H} \\
7,26\end{array}$} & \multirow{3}{*}{$\begin{array}{c}(2) \\
\mathbf{K}_{\mathbf{A}} \\
40\end{array}$} & \multirow{3}{*}{$\begin{array}{c}\mathrm{CaCO}_{3} \\
5,5\end{array}$} & \multicolumn{3}{|c|}{$\mathrm{AL}-\mathrm{P}_{2} \mathrm{O}_{5} \mathrm{mg} / \mathrm{kg}$} \\
\hline & & & & & \multirow{2}{*}{$\begin{array}{r}\mathbf{0 0 0} \\
97\end{array}$} & \multirow{2}{*}{$\begin{array}{l}441 \\
213\end{array}$} & \multirow{2}{*}{$\begin{array}{l}442 \\
207\end{array}$} \\
\hline Nagyhörcsök & $(\mathrm{NH})$ & & & & & & \\
\hline Iregszemcse & (IR) & 7,21 & 42 & 6,2 & 111 & 398 & 394 \\
\hline Mosonmagyaróvár & (MO) & 7,27 & 43 & 19,5 & 201 & 394 & 347 \\
\hline Hajdúböszörmény & (HB) & 6,43 & 54 & - & 38 & 298 & 301 \\
\hline Keszthely & (KE) & 5,92 & 37 & - & 43 & 203 & 208 \\
\hline Karcag & (KA) & 4,56 & 47 & - & 36 & 196 & 194 \\
\hline Kompolt & $(\mathrm{KO})$ & 4,56 & 44 & - & 51 & 255 & 254 \\
\hline Putnok & (PU) & 4,46 & 41 & - & 44 & 142 & 157 \\
\hline Bicsérd & (BI) & 5,61 & 45 & - & 49 & 213 & 207 \\
\hline
\end{tabular}

A kísérleti eredmények értékelése és ábrázolása a STATGRAPHICS számítógépes programcsomag segítségével történt.

\section{Eredmények és értékelésük}

A kísérlet lebontása után meghatároztuk a vágásonkénti szárazanyag-produkciót, majd a növényminták kénsavas feltárását követően az NPK tápelemtartalmat és kiszámítottuk a felvett tápelemmennyiségeket.

A kísérlet eredményeiből az alábbi főbb megállapításokat tettük:

\section{Az angolperje szárazanyag-produkciója}

Az egyes kísérleti helyek talaján kapott szárazanyag-produkció szerinti sorrendben közöljük a kapott eredményeket, a vágásonkénti szárazanyagtömeg összegzése után (2. táblázat).

A frissen adott kezelések hatására a szárazanyag-felhalmozás - föként a 000 alapkezelésre adott tápanyagszinteken - a legtöbb talajnál statisztikailag igazolhatóan megnőtt. Az eredmények értékelése során, a jobb eligazodás érdekében elvégeztük a Duncan-tesztet is (szignifikáns különbség van azon kezelések között, ahol a számértékek melletti betűjelzéseknél különböző betü szerepel).

Figyelemre méltó, hogy a szárazanyag-produkciónál kapott sorrendben mindhárom alapkezelésnél első helyen szerepelt a MO (karbonátos öntés csernozjom), másodikként a BI (mészlepedékes csernozjom) talaj, míg a harmadik a sorrendben a 441 és 442 alapkezelésnél a NH (mészlepedékes csernozjom) talaj volt. 


\section{2. táblázat}

Az angolperje szárazanyag-produkciója az egyes kísérleti helyek talaján beállított tenyészedény-kísérletben (g/edény)

A. 000 alapkezelés

\begin{tabular}{|l|l|l|l|l|l|l|}
\hline \multicolumn{1}{|c|}{$\begin{array}{c}\text { Kísérleti hely } \\
\text { Mosonmagyaróvár }\end{array}$} & \multicolumn{1}{|c|}{$\mathbf{N}_{\mathbf{1}}$} & \multicolumn{1}{|c|}{$\mathbf{N}_{\mathbf{1}} \mathbf{P}_{\mathbf{1}}$} & $\mathbf{N}_{\mathbf{1}} \mathbf{P}_{\mathbf{1}} \mathbf{K}_{\mathbf{1}}$ & \multicolumn{1}{|c|}{$\mathbf{N}_{\mathbf{2}} \mathbf{P}_{\mathbf{2}}$} & $\mathbf{N}_{\mathbf{2}} \mathbf{P}_{\mathbf{2}} \mathbf{K}_{\mathbf{1}}$ & $\mathbf{N}_{\mathbf{2}} \mathbf{P}_{\mathbf{2}} \mathbf{K}_{\mathbf{2}}$ \\
\hline Bicsérd & $14,758 \mathrm{~b}$ & $18,315 \mathrm{~b}$ & $18,838 \mathrm{~b}$ & $12,68 \mathrm{a}$ & $25,185 \mathrm{c}$ & $23,858 \mathrm{c}$ \\
Kompolt & $12,853 \mathrm{a}$ & $14,630 \mathrm{a}$ & $16,340 \mathrm{ab}$ & $14,513 \mathrm{a}$ & $16,080 \mathrm{ab}$ & $18,980 \mathrm{~b}$ \\
Putnok & $12,385 \mathrm{ab}$ & $14,277 \mathrm{bc}$ & $15,3705 \mathrm{a}$ & $14,020 \mathrm{a}$ & $15,460 \mathrm{a}$ & $18,468 \mathrm{~b}$ \\
Nagyhörcsök & $11,935 \mathrm{a}$ & $15,842 \mathrm{bc}$ & $16,595 \mathrm{c}$ & $11,838 \mathrm{a}$ & $17,613 \mathrm{~d}$ & $17,005 \mathrm{~d}$ \\
Iregszemcse & $10,695 \mathrm{ab}$ & $10,160 \mathrm{a}$ & $13,058 \mathrm{c}$ & $9,598 \mathrm{a}$ & $18,160 \mathrm{c}$ & $18,575 \mathrm{c}$ \\
Karcag & $10,310 \mathrm{a}$ & $13,850 \mathrm{bc}$ & $13,590 \mathrm{bc}$ & $11,333 \mathrm{a}$ & $12,125 \mathrm{ab}$ & $14,095 \mathrm{c}$ \\
Keszthely & $9,378 \mathrm{a}$ & $11,003 \mathrm{ab}$ & $13,200 \mathrm{c}$ & $9,640 \mathrm{ab}$ & $11,625 \mathrm{bc}$ & $13,143 \mathrm{c}$ \\
Hajdúböszörmény & $8,248 \mathrm{a}$ & $11,573 \mathrm{~b}$ & $13,390 \mathrm{bc}$ & $11,635 \mathrm{~b}$ & $11,560 \mathrm{~b}$ & $14,882 \mathrm{c}$ \\
\hline
\end{tabular}

B. 441 alapkezelés

\begin{tabular}{|l|l|l|l|l|}
\hline \multicolumn{1}{|c|}{ Kísérleti hely } & \multicolumn{1}{c|}{$\mathbf{N}_{\mathbf{1}}$} & \multicolumn{1}{c|}{$\mathbf{N}_{\mathbf{1}} \mathbf{P}_{\mathbf{1}}$} & \multicolumn{1}{c|}{$\mathbf{N}_{\mathbf{1}} \mathbf{P}_{\mathbf{1}} \mathbf{K}_{\mathbf{1}}$} & $\mathbf{N}_{\mathbf{1}} \mathbf{P}_{\mathbf{1}} \mathbf{K}_{\mathbf{2}}$ \\
\hline Mosonmagyaróvár & $19,947 \mathrm{a}$ & $20,093 \mathrm{a}$ & $19,723 \mathrm{a}$ & $20,768 \mathrm{a}$ \\
Bicsérd & $17,313 \mathrm{a}$ & $17,728 \mathrm{a}$ & $20,890 \mathrm{~b}$ & $19,958 \mathrm{ab}$ \\
Nagyhörcsök & $15,810 \mathrm{a}$ & $17,115 \mathrm{a}$ & $18,008 \mathrm{a}$ & $18,080 \mathrm{a}$ \\
Kompolt & $14,445 \mathrm{a}$ & $14,895 \mathrm{ab}$ & $16,103 \mathrm{~b}$ & $17,815 \mathrm{c}$ \\
Iregszemcse & $13,5689 \mathrm{a}$ & $13,3825 \mathrm{a}$ & $15,7325 \mathrm{~b}$ & $16,4650 \mathrm{~b}$ \\
Hajdúböszörmény & $13,278 \mathrm{a}$ & $13,605 \mathrm{a}$ & $15,515 \mathrm{a}$ & $15,320 \mathrm{a}$ \\
Putnok & $12,955 \mathrm{a}$ & $13,655 \mathrm{ab}$ & $14,770 \mathrm{bc}$ & $16,017 \mathrm{c}$ \\
Keszthely & $12,130 \mathrm{a}$ & $12,230 \mathrm{a}$ & $14,375 \mathrm{~b}$ & $15,275 \mathrm{~b}$ \\
Karcag & $9,705 \mathrm{a}$ & $11,468 \mathrm{ab}$ & $10,788 \mathrm{ab}$ & $12,848 \mathrm{~b}$ \\
\hline
\end{tabular}

C. 442 alapkezelés

\begin{tabular}{|l|l|l|l|l|}
\hline \multicolumn{1}{|c|}{ Kísérleti hely } & \multicolumn{1}{c|}{$\mathbf{N}_{\mathbf{1}}$} & $\mathbf{N}_{\mathbf{1}} \mathbf{P}_{\mathbf{1}}$ & $\mathbf{N}_{\mathbf{1}} \mathbf{P}_{\mathbf{1}} \mathbf{K}_{\mathbf{1}}$ & $\mathbf{N}_{\mathbf{1}} \mathbf{P}_{\mathbf{1}} \mathbf{K}_{\mathbf{2}}$ \\
\hline Mosonmagyaróvár & $20,21 \mathrm{a}$ & $20,193 \mathrm{a}$ & $19,763 \mathrm{a}$ & $21,64 \mathrm{a}$ \\
Bicsérd & $18,715 \mathrm{a}$ & $19,793 \mathrm{ab}$ & $20,393 \mathrm{~b}$ & $19,975 \mathrm{ab}$ \\
Nagyhörcsök & $15,890 \mathrm{a}$ & $16,115 \mathrm{a}$ & $15,543 \mathrm{a}$ & $16,968 \mathrm{a}$ \\
Iregszemcse & $15,670 \mathrm{a}$ & $15,917 \mathrm{a}$ & $16,208 \mathrm{a}$ & $16,830 \mathrm{a}$ \\
Putnok & $15,413 \mathrm{a}$ & $16,530 \mathrm{a}$ & $16,413 \mathrm{a}$ & $16,447 \mathrm{a}$ \\
Hajdúböszörmény & $14,585 \mathrm{a}$ & $13,993 \mathrm{a}$ & $14,805 \mathrm{a}$ & $14,863 \mathrm{a}$ \\
Kompolt & $13,333 \mathrm{a}$ & $14,038 \mathrm{ab}$ & $14,848 \mathrm{ab}$ & $15,895 \mathrm{~b}$ \\
Keszthely & $13,280 \mathrm{a}$ & $13,555 \mathrm{a}$ & $14,480 \mathrm{a}$ & $15,153 \mathrm{a}$ \\
Karcag & $10,273 \mathrm{a}$ & $11,170 \mathrm{ab}$ & $11,460 \mathrm{ab}$ & $12,310 \mathrm{~b}$ \\
\hline
\end{tabular}




\section{3. táblázat}

Az angolperje által felvett foszfor átlagai a tenyészedény-kísérletben ( $\mathrm{mg} \mathrm{P}_{2} \mathrm{O}_{5}$ /edény)

A. 000 alapkezelés

\begin{tabular}{|l|c|c|c|c|c|c|}
\hline \multicolumn{1}{|c|}{$\begin{array}{c}(1) \\
\text { Kísérleti hely }\end{array}$} & $\mathbf{N}_{\mathbf{1}}$ & $\mathbf{N}_{\mathbf{1}} \mathbf{P}_{\mathbf{1}}$ & $\mathbf{N}_{\mathbf{1}} \mathbf{P}_{\mathbf{1}} \mathbf{K}_{\mathbf{1}}$ & $\mathbf{N}_{\mathbf{2}} \mathbf{P}_{\mathbf{2}}$ & $\mathbf{N}_{\mathbf{2}} \mathbf{P}_{\mathbf{2}} \mathbf{K}_{\mathbf{1}}$ & $\mathbf{N}_{\mathbf{2}} \mathbf{P}_{\mathbf{2}} \mathbf{K}_{\mathbf{2}}$ \\
\hline M.óvár & $21,5576 \mathrm{a}$ & $35,8519 \mathrm{c}$ & $33,5466 \mathrm{bc}$ & $29,0699 \mathrm{~b}$ & $45,5619 \mathrm{~d}$ & $42,3179 \mathrm{~d}$ \\
Kompolt & $19,5053 \mathrm{a}$ & $39,2482 \mathrm{~b}$ & $40,5175 \mathrm{~b}$ & $48,8237 \mathrm{c}$ & $54,4956 \mathrm{~cd}$ & $60,5971 \mathrm{~d}$ \\
Bicsérd & $18,7220 \mathrm{a}$ & $34,3565 \mathrm{~b}$ & $35,8927 \mathrm{~b}$ & $38,7997 \mathrm{bc}$ & $44,6291 \mathrm{c}$ & $51,7179 \mathrm{~d}$ \\
Iregszemcse & $18,2012 \mathrm{a}$ & $30,8826 \mathrm{~b}$ & $33,165 \mathrm{~b}$ & $33,8802 \mathrm{~b}$ & $38,0239 \mathrm{c}$ & $40,6702 \mathrm{c}$ \\
Karcag & $16,7147 \mathrm{a}$ & $41,7314 \mathrm{~b}$ & $39,4002 \mathrm{~b}$ & $41,8093 \mathrm{~b}$ & $40,8695 \mathrm{~b}$ & $44,8922 \mathrm{~b}$ \\
Putnok & $13,5499 \mathrm{a}$ & $28,8192 \mathrm{~b}$ & $31,8593 \mathrm{~b}$ & $31,5190 \mathrm{~b}$ & $44,2709 \mathrm{c}$ & $43,8273 \mathrm{c}$ \\
Keszthely & $13,2141 \mathrm{a}$ & $27,5844 \mathrm{~b}$ & $34,6844 \mathrm{c}$ & $39,1985 \mathrm{~cd}$ & $43,4163 \mathrm{de}$ & $47,2364 \mathrm{e}$ \\
N.hörcsök & $11,2447 \mathrm{a}$ & $27,3800 \mathrm{~b}$ & $28,8228 \mathrm{~b}$ & $31,0958 \mathrm{~b}$ & $37,0076 \mathrm{c}$ & $38,0871 \mathrm{c}$ \\
H.böszörmény & $4,9917 \mathrm{a}$ & $18,4189 \mathrm{~b}$ & $22,8343 \mathrm{bc}$ & $24,8791 \mathrm{bcd}$ & $26,9663 \mathrm{~cd}$ & $31,5209 \mathrm{e}$ \\
\hline
\end{tabular}

B. 441 alapkezelés

\begin{tabular}{|l|c|l|l|l|}
\hline \multicolumn{1}{|c|}{ Kísérleti hely } & \multicolumn{1}{c|}{$\mathbf{N}_{\mathbf{1}}$} & \multicolumn{1}{c|}{$\mathbf{N}_{\mathbf{1}} \mathbf{P}_{\mathbf{1}}$} & $\mathbf{N}_{\mathbf{1}} \mathbf{P}_{\mathbf{1}} \mathbf{K}_{\mathbf{1}}$ & $\mathbf{N}_{\mathbf{1}} \mathbf{P}_{\mathbf{1}} \mathbf{K}_{\mathbf{2}}$ \\
\hline Kompolt & $49,2764 \mathrm{a}$ & $59,2217 \mathrm{~b}$ & $62,8856 \mathrm{~b}$ & $64,3195 \mathrm{~b}$ \\
Bicsérd & $40,1121 \mathrm{a}$ & $47,1114 \mathrm{ab}$ & $53,6618 \mathrm{~b}$ & $48,9622 \mathrm{~b}$ \\
Keszthely & $36,5250 \mathrm{a}$ & $47,0454 \mathrm{~b}$ & $53,8400 \mathrm{~b}$ & $53,2731 \mathrm{~b}$ \\
Mosonmagyaróvár & $36,5032 \mathrm{a}$ & $46,8305 \mathrm{~b}$ & $46,1540 \mathrm{~b}$ & $46,1058 \mathrm{~b}$ \\
Iregszemcse & $33,8048 \mathrm{a}$ & $42,4628 \mathrm{~b}$ & $47,6131 \mathrm{c}$ & $46,8542 \mathrm{~b}$ \\
Nagyhörcsök & $32,9100 \mathrm{a}$ & $39,7939 \mathrm{~b}$ & $38,6880 \mathrm{~b}$ & $35,9629 \mathrm{ab}$ \\
Karcag & $32,6657 \mathrm{a}$ & $45,5110 \mathrm{~b}$ & $41,9971 \mathrm{~b}$ & $48,6162 \mathrm{~b}$ \\
Hajdúböszörmény & $24,5265 \mathrm{a}$ & $30,5219 \mathrm{ab}$ & $35,5492 \mathrm{~b}$ & $37,0377 \mathrm{~b}$ \\
Putnok & $26,4498 \mathrm{a}$ & $35,5754 \mathrm{~b}$ & $39,5075 \mathrm{c}$ & $39,7341 \mathrm{c}$ \\
\hline
\end{tabular}

C. 442 alapkezelés

\begin{tabular}{|l|c|c|c|c|}
\hline \multicolumn{1}{|c|}{ Kísérleti hely } & $\mathbf{N}_{\mathbf{1}}$ & $\mathbf{N}_{\mathbf{1}} \mathbf{P}_{\mathbf{1}}$ & $\mathbf{N}_{\mathbf{1}} \mathbf{P}_{\mathbf{1}} \mathbf{K}_{\mathbf{1}}$ & $\mathbf{N}_{\mathbf{1}} \mathbf{P}_{\mathbf{1}} \mathbf{K}_{\mathbf{2}}$ \\
\hline Kompolt & $47,6193 \mathrm{a}$ & $56,8322 \mathrm{~b}$ & $59,0121 \mathrm{~b}$ & $58,3052 \mathrm{~b}$ \\
Keszthely & $47,3951 \mathrm{a}$ & $56,1767 \mathrm{~b}$ & $58,6903 \mathrm{~b}$ & $59,5603 \mathrm{~b}$ \\
Bicsérd & $41,8860 \mathrm{a}$ & $51,7485 \mathrm{~b}$ & $52,3669 \mathrm{~b}$ & $50,4775 \mathrm{~b}$ \\
Mosonmagyaróvár & $39,0679 \mathrm{a}$ & $44,8701 \mathrm{a}$ & $43,8579 \mathrm{bc}$ & $40,4875 \mathrm{ab}$ \\
Iregszemcse & $39,0477 \mathrm{a}$ & $44,9385 \mathrm{~b}$ & $45,2378 \mathrm{~b}$ & $44,8840 \mathrm{~b}$ \\
Putnok & $36,1546 \mathrm{a}$ & $44,4963 \mathrm{~b}$ & $48,4487 \mathrm{~b}$ & $47,2380 \mathrm{~b}$ \\
Karcag & $35,8793 \mathrm{a}$ & $44,7090 \mathrm{~b}$ & $45,2962 \mathrm{~b}$ & $44,4681 \mathrm{~b}$ \\
Nagyhörcsök & $32,8227 \mathrm{a}$ & $38,1909 \mathrm{~b}$ & $38,7271 \mathrm{~b}$ & $40,9881 \mathrm{~b}$ \\
Hajdúböszörmény & $25,9927 \mathrm{a}$ & $29,8652 \mathrm{ab}$ & $36,6630 \mathrm{~b}$ & $35,7117 \mathrm{~b}$ \\
\hline
\end{tabular}


Az angolperje által kivont foszfor mennyisége

$\mathrm{Az}$ angolperje által az 5 vágás során összesen felvett foszfor $\left(\mathrm{P}_{2} \mathrm{O}_{5} \mathrm{mg} / \mathrm{kg}\right)$ mennyisége talajtípusonként jelentős, a legtöbb kezelésnél a kontrollhoz képest szignifikáns különbségeket mutatott (3. táblázat). Míg a trágyázatlan kontroll alapkezelésnél a szárazanyag-produkcióhoz hasonlóan a MO talaj volt az első, a legnagyobb mértékủ P-felhalmozás a kompolti talajon (KO) a 441 alapkezelésnél alkalmazott $\mathrm{N}_{1} \mathrm{P}_{1} \mathrm{~K}_{2}$-adagnál mutatkozott (64,3 mg $\mathrm{P}_{2} \mathrm{O}_{5}$ /edény, ill. $\mathrm{kg}$ talaj).

Érdemes megemlíteni, hogy eredményeink a N:P:K kölcsönhatások jelentőségét alátámasztó, füfajokra is vonatkozó kísérleti eredményekkel összhangban vannak. A három tápelem együttes hatására vonatkozó közlemények arról számolnak be, hogy a növények szükségletéhez igazodó P-kijuttatás kedvezően befolyásolta a $\mathrm{N}$ - és K-hatásokat és így eredményezte a legnagyobb termést (WILKINSON et al., 2000).

A kisérleti talajok P szolgáltatása, ill. adszorpciója

A kiinduláskor mért P-tartalom, a kezelésekben hozzáadott mennyiségek, a kísérlet lebontását követően az egyes kezelésekben mért $\mathrm{AL}-\mathrm{P}_{2} \mathrm{O}_{5}$ mennyiségek (AL- $\mathrm{P}_{2} \mathrm{O}_{5} \mathrm{mg} / \mathrm{kg}$ talaj) (4. táblázat), valamint az angolperje által kivont P-menynyiségek összevetésével kiszámítottuk az egyes talajokon mindhárom alapkezelésnél az esetleges P-szolgáltatás, valamint a foszfor adszorpciójának mértékét. Az eredményeket az 1.-9. ábrán közöljük (a jobb érthetőség céljából egy leegyszerüsített ábrázolási módot alkalmaztunk, amelynek segítségével látható az egyes talajok és a tartam P-hatásból származó különbségek). A talajok sorrendjének megállapításakor a trágyázatlan kontrollnál kapott nagyság szerinti sorrendet követtük.

A tenyészedény-kísérletben kezelésenként kiszámított P-egyenleg átlagolásával, az egyes talajoknál alapkezelésenként, valamint a talajonként az alapkezelések átlagában is adódott egy - a foszfor átalakulására jellemző - sorrend. Az eredményeket a 10. ábrán mutatjuk be. Az ábra alapján jól nyomon követhető, hogy ez a sorrend a 000 alapkezelésnél, tehát a trágyázatlan kontrollnál határozott kapcsolatot mutat a talajok kémhatásával, bár nem teljesen követi azt. Figyelemre méltó, hogy a trágyázatlan kontrollnál, a pH csökkenésével szinte teljesen megegyező módon, egyre fokozódó mértékü P-lekötődés mutatkozott, az irodalmi adatokkal összhangban.

A 10. ábrán egyértelmủen látható, hogy a legnagyobb mértékủ P-lekötődés a trágyázatlan kontrolltalajokon mutatkozott és ez a 441 és a 442 alapkezelésnél a tartam mütrágyázás következtében számottevően csökkent. Annak tisztázására, hogy a 442 alapkezelésnél miért volt jelentősen kisebb P-lekötődés, további elemzéseket tartunk szükségesnek.

A trágyázatlan kontroll esetében és az alapkezeléseket átlagolva, a talajok közül a MO talajnál mutatkozott a legcsekélyebb mértékü P-lekötődés (átla- 
4. táblázat

A talajok AL- $\mathrm{P}_{2} \mathrm{O}_{5}$ tartalma a tenyészedény-kísérlet végén $\left(\mathrm{mg} \mathrm{P}_{2} \mathrm{O}_{5} / \mathrm{kg}\right.$ talaj)

A. 000 alapkezelés

\begin{tabular}{|l|c|c|c|c|c|c|}
\hline \multicolumn{1}{|c|}{ Kísérleti hely } & $\mathbf{N}_{\mathbf{1}}$ & $\mathbf{N}_{\mathbf{1}} \mathbf{P}_{\mathbf{1}}$ & $\mathbf{N}_{\mathbf{1}} \mathbf{P}_{\mathbf{1}} \mathbf{K}_{\mathbf{1}}$ & $\mathbf{N}_{\mathbf{2}} \mathbf{P}_{\mathbf{2}}$ & $\mathbf{N}_{\mathbf{2}} \mathbf{P}_{\mathbf{2}} \mathbf{K}_{\mathbf{1}}$ & $\mathbf{N}_{\mathbf{2}} \mathbf{P}_{\mathbf{2}} \mathbf{K}_{\mathbf{2}}$ \\
\hline Mosonmagyaróvár & 194 & 315 & 325 & 544 & 582 & 544 \\
Kompolt & 6 & 71 & 55 & 155 & 158 & 126 \\
Bicsérd & 11 & 59 & 53 & 117 & 127 & 132 \\
Iregszemcse & 117 & 231 & 228 & 353 & 346 & 380 \\
Karcag & 4 & 68 & 37 & 103 & 198 & 94 \\
Putnok & 5 & 53 & 43 & 112 & 114 & 113 \\
Keszthely & 18 & 84 & 62 & 174 & 145 & 151 \\
Nagyhörcsök & 57 & 167 & 164 & 263 & 245 & 292 \\
Hajdúböszörmény & 15 & 99 & 87 & 223 & 255 & 241 \\
\hline
\end{tabular}

B. 441 alapkezelés

\begin{tabular}{|l|c|c|c|c|}
\hline \multicolumn{1}{|c|}{ Kísérleti hely } & $\mathbf{N}_{\mathbf{1}}$ & $\mathbf{N}_{\mathbf{1}} \mathbf{P}_{\mathbf{1}}$ & $\mathbf{N}_{\mathbf{1}} \mathbf{P}_{\mathbf{1}} \mathbf{K}_{\mathbf{1}}$ & $\mathbf{N}_{\mathbf{1}} \mathbf{P}_{\mathbf{1}} \mathbf{K}_{\mathbf{2}}$ \\
\hline Kompolt & 185 & 226 & 289 & 295 \\
Bicsérd & 105 & 245 & 216 & 212 \\
Keszthely & 104 & 253 & 256 & 217 \\
Mosonmagyaróvár & 298 & 439 & 348 & 435 \\
Iregszemcse & 287 & 419 & 429 & 418 \\
Nagyhörcsök & 362 & 513 & 530 & 533 \\
Karcag & 124 & 211 & 265 & 252 \\
Hajdúböszörmény & 245 & 392 & 387 & 357 \\
Putnok & 70 & 116 & 129 & 109 \\
\hline
\end{tabular}

C. 442 alapkezelés

\begin{tabular}{|l|c|c|c|c|}
\hline \multicolumn{1}{|c|}{ Kísérleti hely } & $\mathbf{N}_{\mathbf{1}}$ & $\mathbf{N}_{\mathbf{1}} \mathbf{P}_{\mathbf{1}}$ & $\mathbf{N}_{\mathbf{1}} \mathbf{P}_{\mathbf{1}} \mathbf{K}_{\mathbf{1}}$ & $\mathbf{N}_{\mathbf{1}} \mathbf{P}_{\mathbf{1}} \mathbf{K}_{\mathbf{2}}$ \\
\hline Kompolt & 176 & 334 & 294 & 278 \\
Keszthely & 147 & 294 & 295 & 306 \\
Bicsérd & 72 & 228 & 230 & 249 \\
Mosonmagyaróvár & 293 & 445 & 447 & 469 \\
Iregszemcse & 274 & 415 & 404 & 446 \\
Putnok & 74 & 135 & 134 & 160 \\
Karcag & 140 & 272 & 270 & 254 \\
Nagyhörcsök & 347 & 517 & 531 & 549 \\
Hajdúböszörmény & 221 & 346 & 368 & 338 \\
\hline
\end{tabular}




\section{$\mathrm{mg} / \mathrm{kg} \quad$ Mosonmagyaróvár $(000)$}
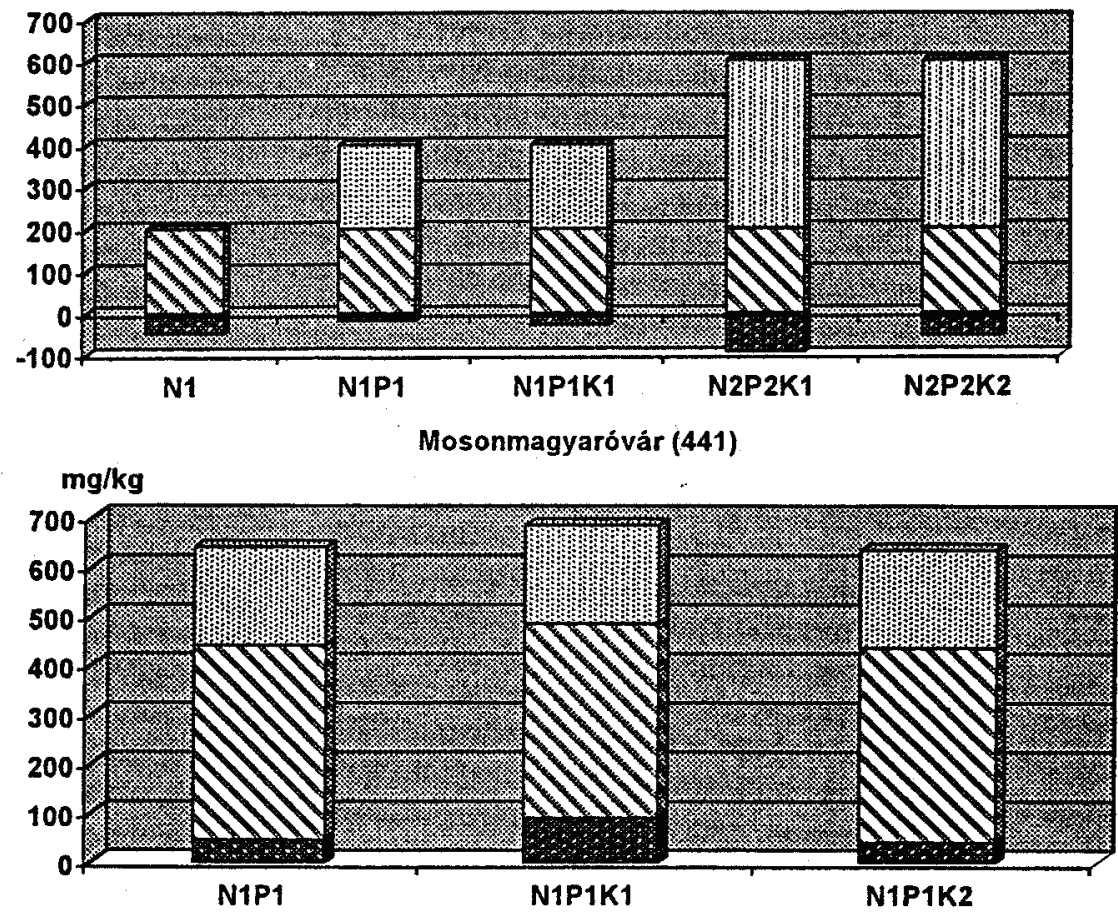

$\mathrm{mg} / \mathrm{kg}$

Mosonmagyaróvár (442))

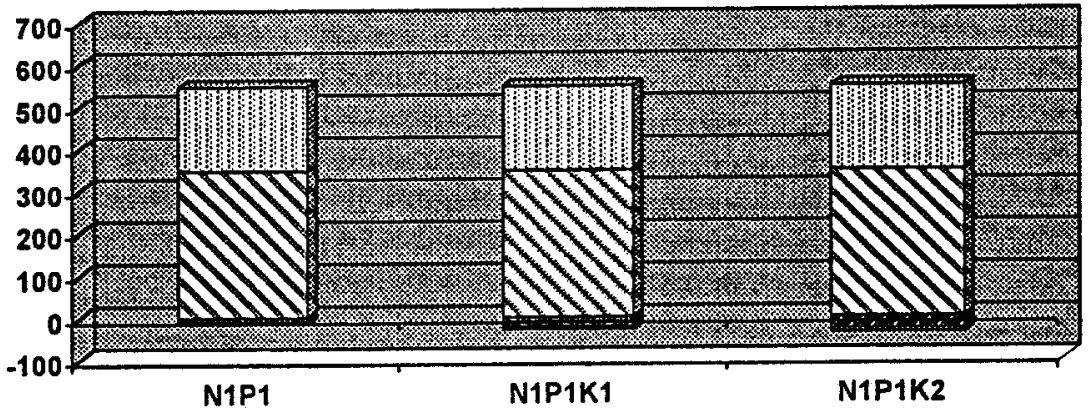

D Szolg.ill.adszorpció Q Kiind.AL-P2O5 GHozzáadott

\section{1. ábra}

A mosonmagyaróvári (MO) talaj P-szolgáltatása, ill. -adszorpciója ( $\mathrm{mg} \mathrm{P}_{2} \mathrm{O}_{5} / \mathrm{kg}$ ) a) P-szolgáltatás ill. adszorpció, b) kiindulási $\mathrm{AL}-\mathrm{P}_{2} \mathrm{O}_{5}, \mathrm{c}$ ) a kezelésekben hozzáadott $\mathrm{P}$ A. 000, B. 441, C. 442 alapkezelés 


$\mathrm{mg} / \mathrm{kg} \quad$ Iregszemcse (000)
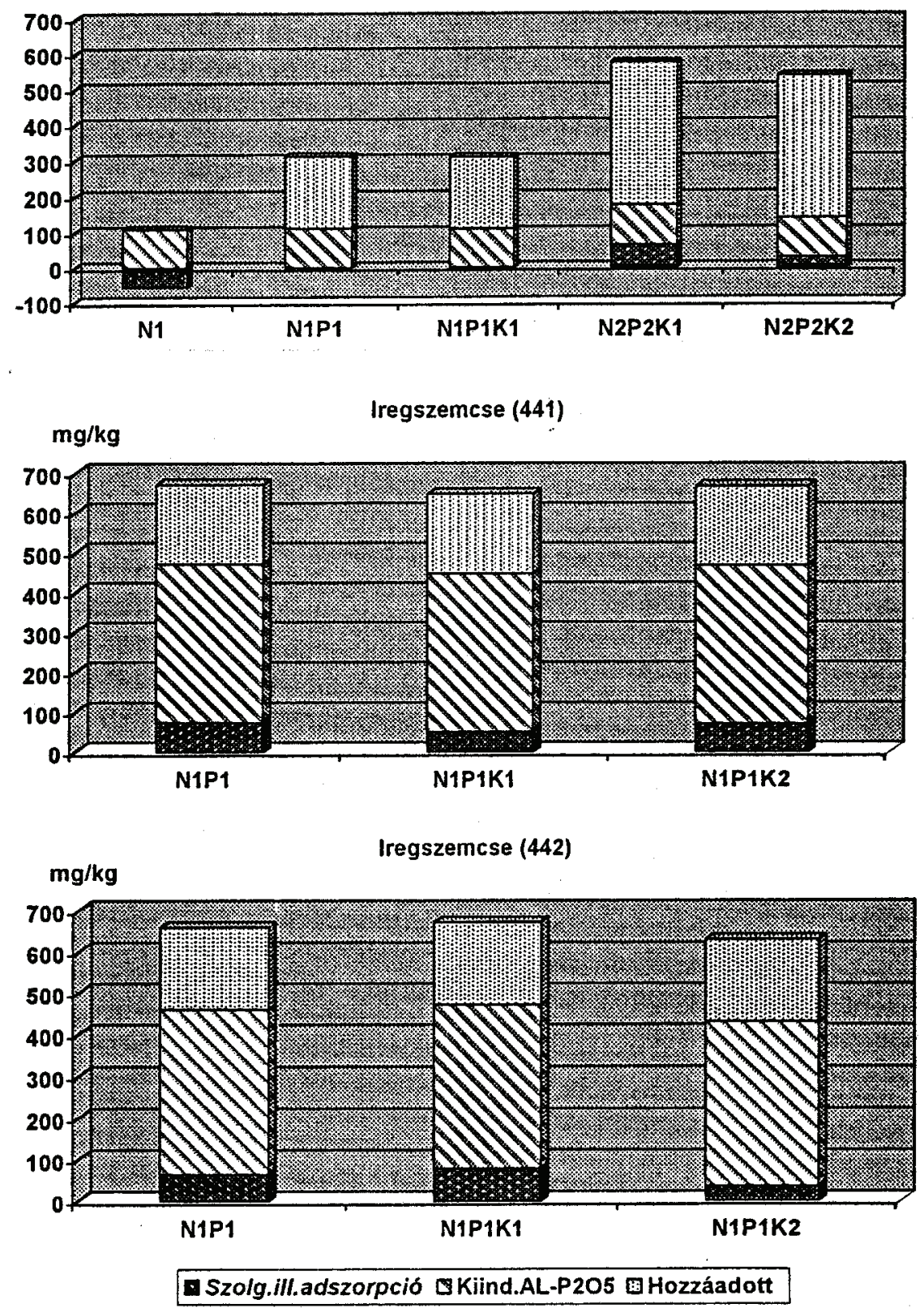

2. ábra

Az iregszemcsei (IR) talaj P-szolgáltatása, ill. -adszorpciója $\left(\mathrm{mg}_{2} \mathrm{O}_{5} / \mathrm{kg}\right)$ a)-c, A-C: lásd 1. ábra 


\section{$\mathbf{m g} / \mathbf{k g}$ \\ Hajdúböszöméné (000)}

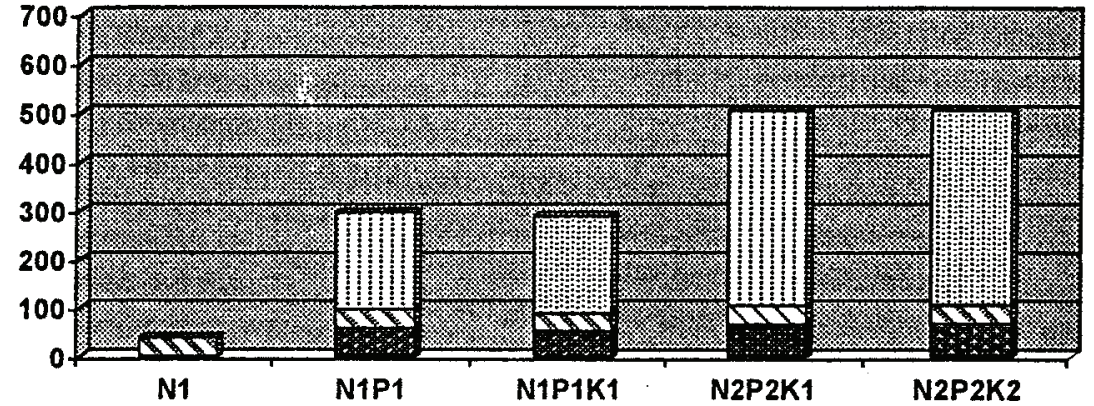

$\mathbf{m g} / \mathbf{k g}$

Hajdúböszörmény (441)

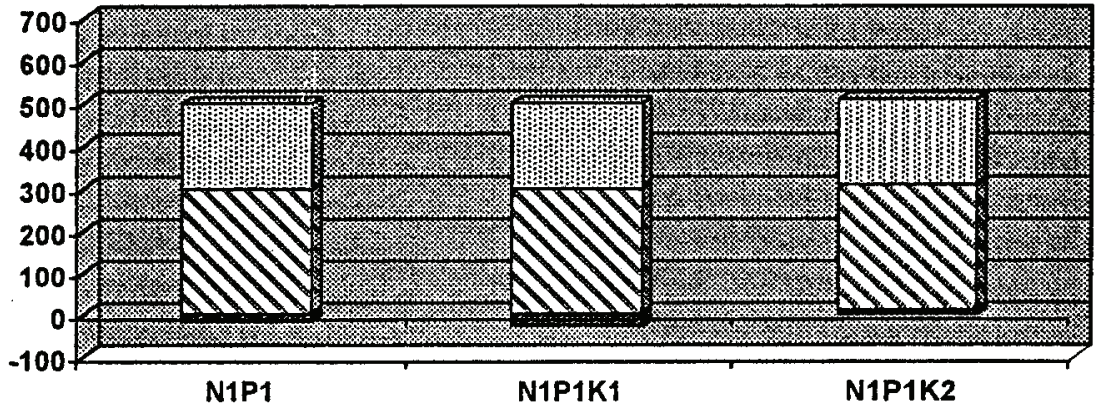

$\mathrm{mg} / \mathrm{kg}$

Hajdüböszörmény (442)

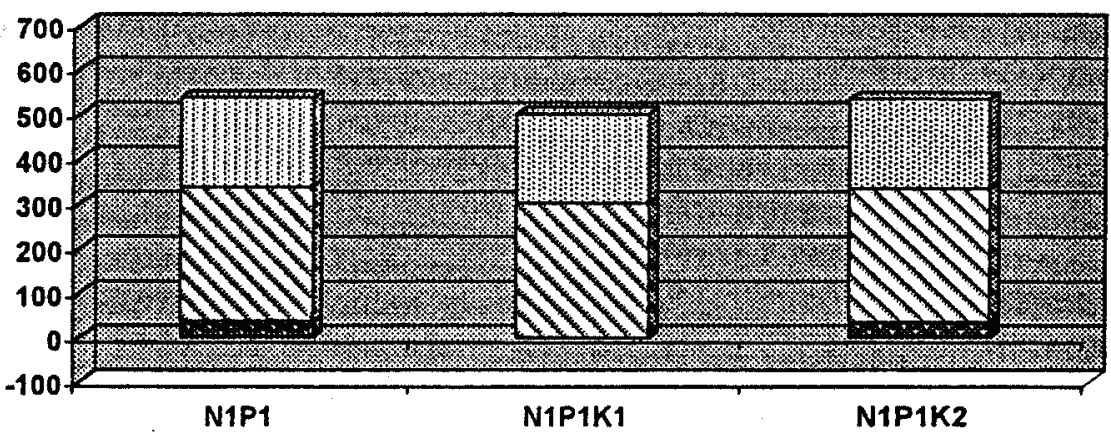

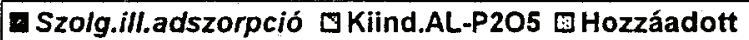

3. ábra

A hajdúböszörményi (HB) talaj P-szolgáltatása, ill. -adszorpciója $\left(\mathrm{mg}_{2} \mathrm{P}_{5} / \mathrm{kg}\right)$ a)-c, A-C: lásd 1. ábra 
$\mathrm{mg} / \mathrm{kg} \quad$ Nagyhörcsök (000)
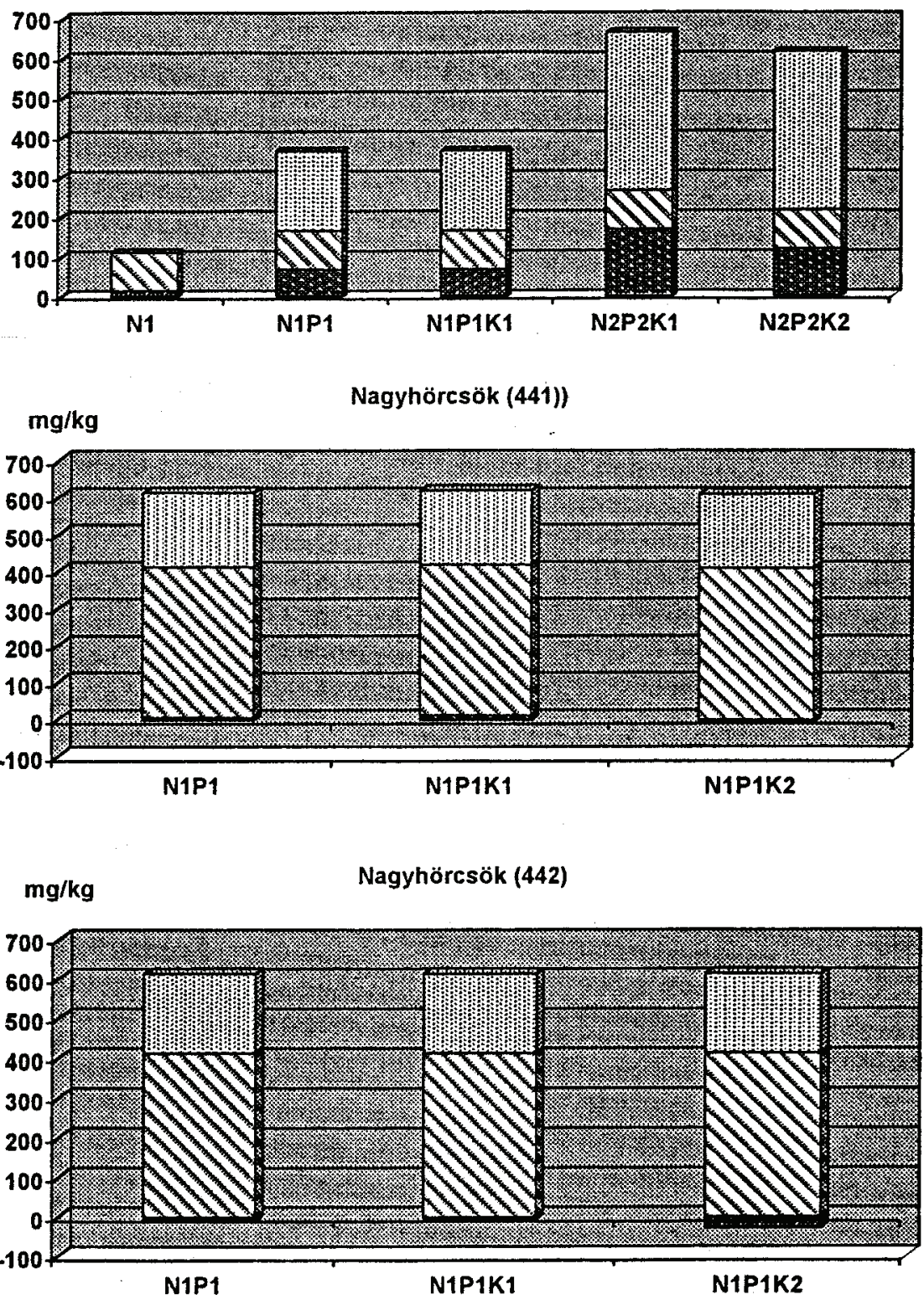

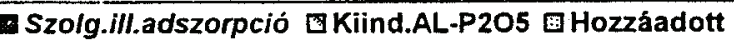

\section{4. ábra}

A nagyhörcsöki (NH) talaj P-szolgáltatása, ill. -adszorpciója $\left(\mathrm{mg}_{2} \mathrm{P}_{5} / \mathrm{kg}\right)$ a)-c, A-C: lásd 1. ábra 

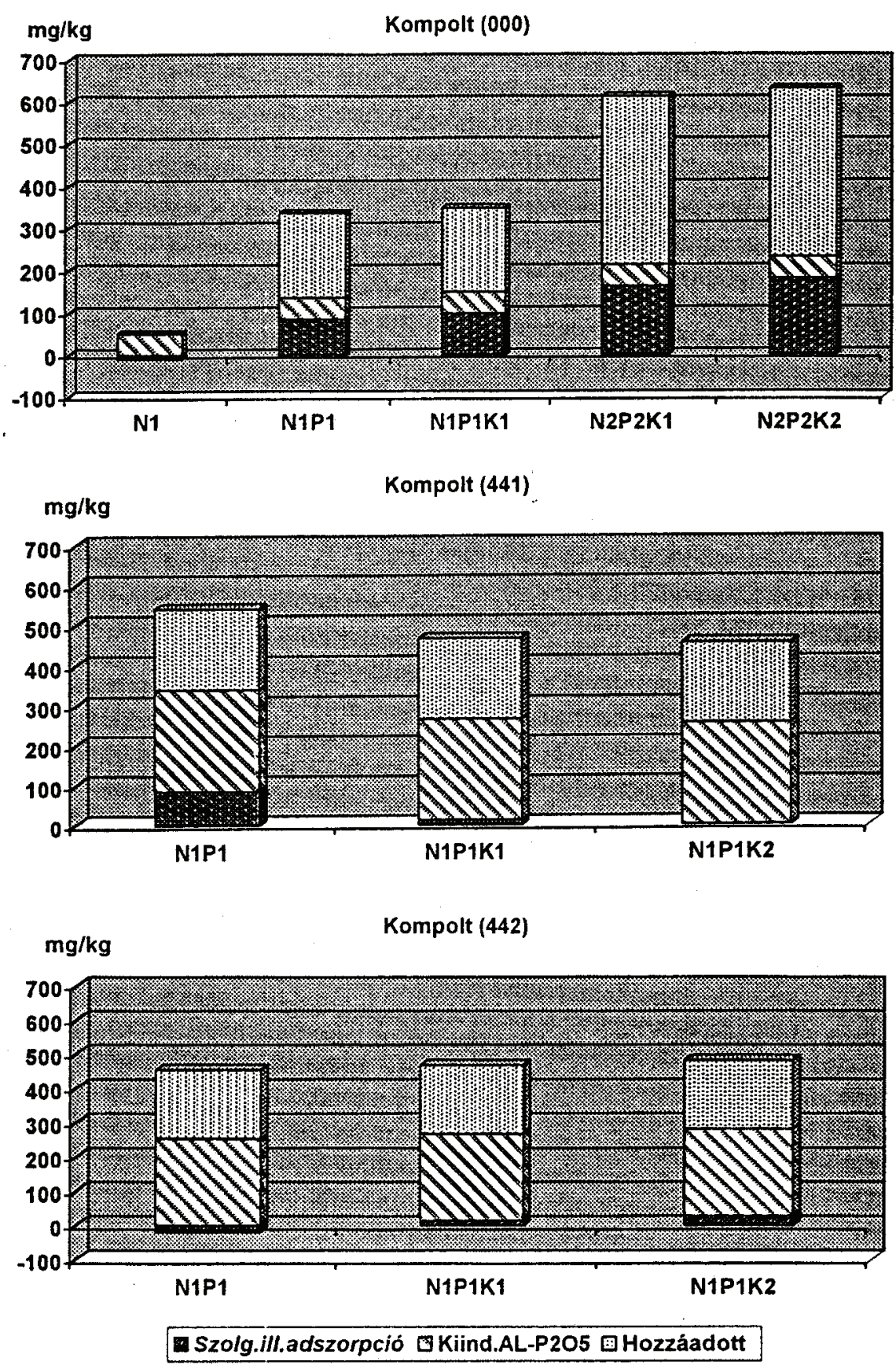

\section{5. ábra}

A kompolti (KO) talaj P-szolgáltatása, ill. -adszorpciója ( $\left.\mathrm{mg} \mathrm{P}_{2} \mathrm{O}_{5} / \mathrm{kg}\right)$

a)-c, A-C: lásd 1. ábra 

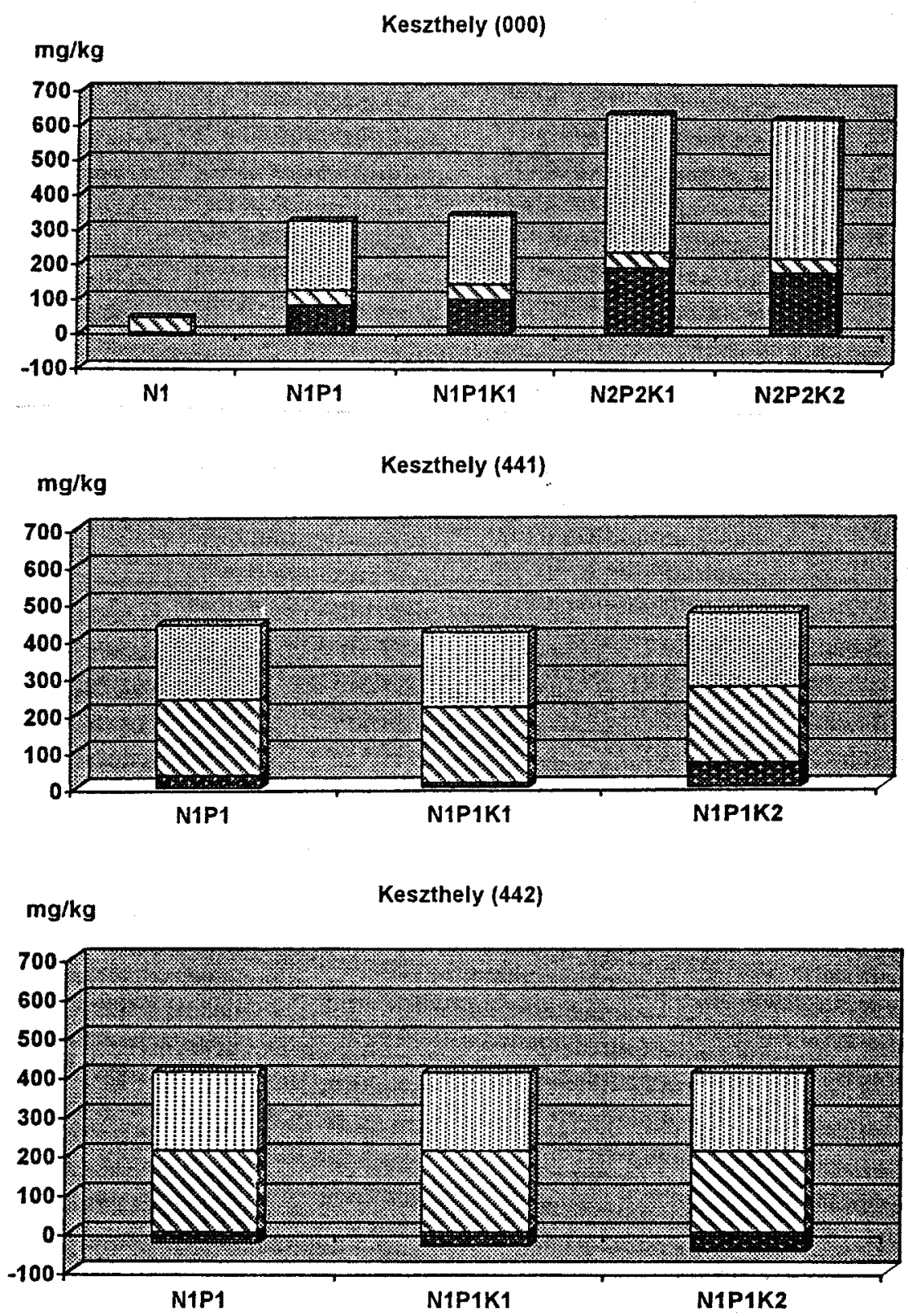

Szolg.ill.adszorpció Q Kiind.AL-P2O5 GHozzáadott

\section{6. ábra}

A keszthelyi (KE) talaj P-szolgáltatása, ill. -adszorpciója $\left(m g \mathrm{P}_{2} \mathrm{O}_{5} / \mathrm{kg}\right)$ a)-c, A-C: lásd 1. ábra 

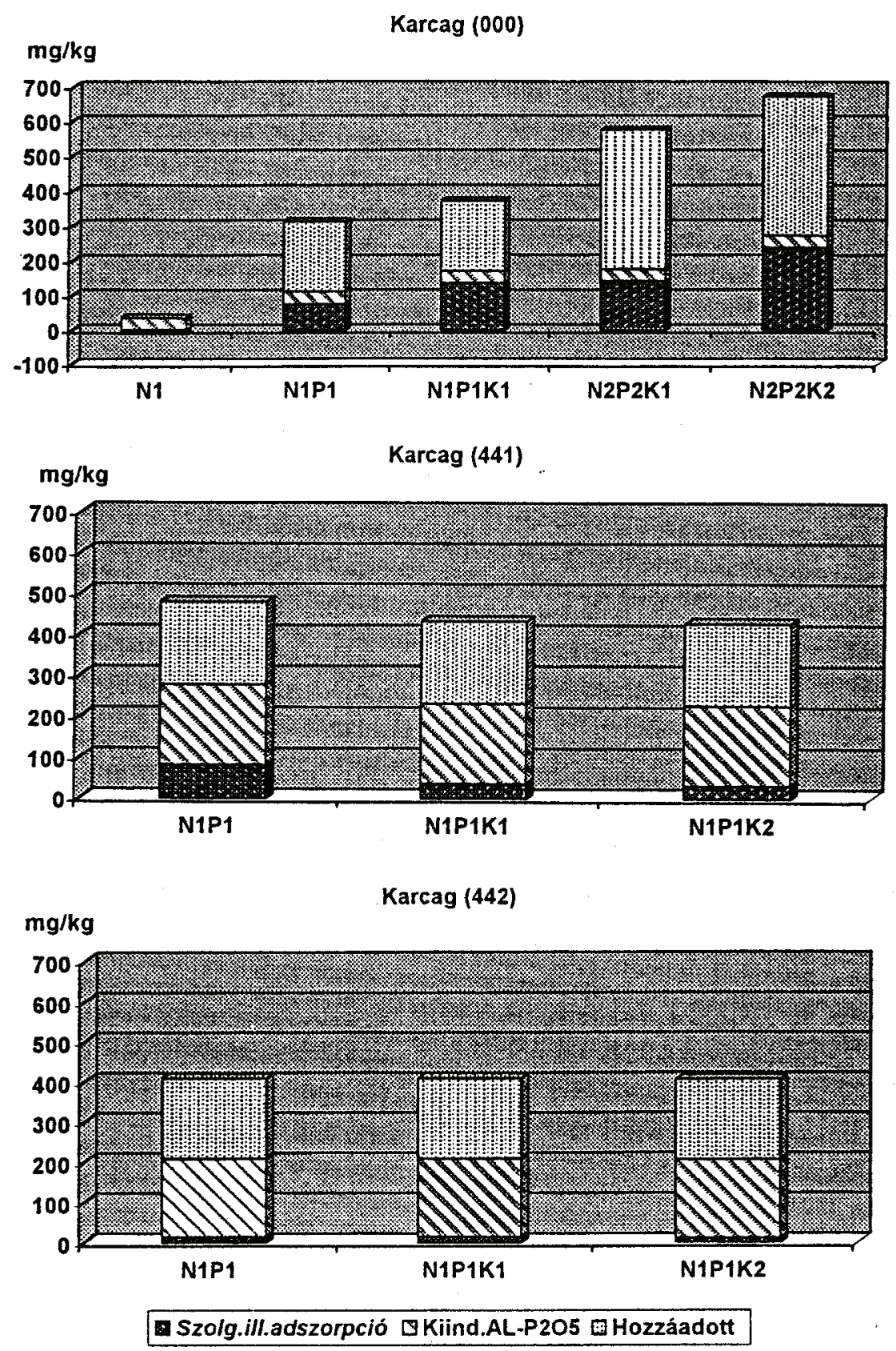

7. ábra

A karcagi (KA) talaj P-szolgáltatása, ill. -adszorpciója $\left(\mathrm{mg} \mathrm{P}_{2} \mathrm{O}_{5} / \mathrm{kg}\right)$

a)-c, A-C: lásd 1. ábra 

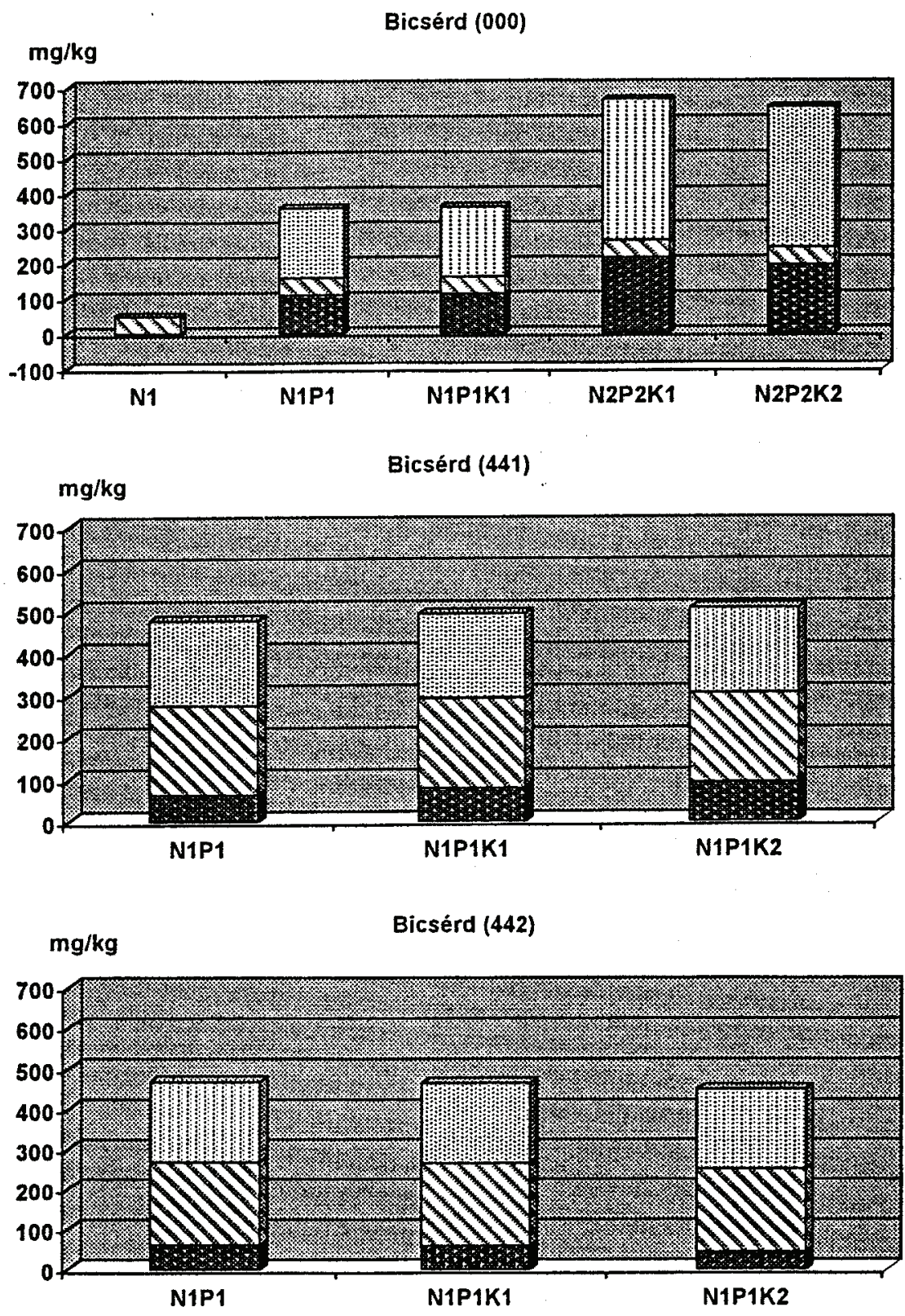

Szolg.ill.adszorpció \$Kiind.AL-P2O5 GHozzáadott

8. ábra

A bicsérdi (BI) talaj P-szolgáltatása, ill. -adszorpciója $\left(\mathrm{mg} \mathrm{P}_{2} \mathrm{O}_{5} / \mathrm{kg}\right)$

a)-c, A-C: lásd 1. ábra 
$\mathrm{mg} / \mathrm{kg}$

Putnok (000)
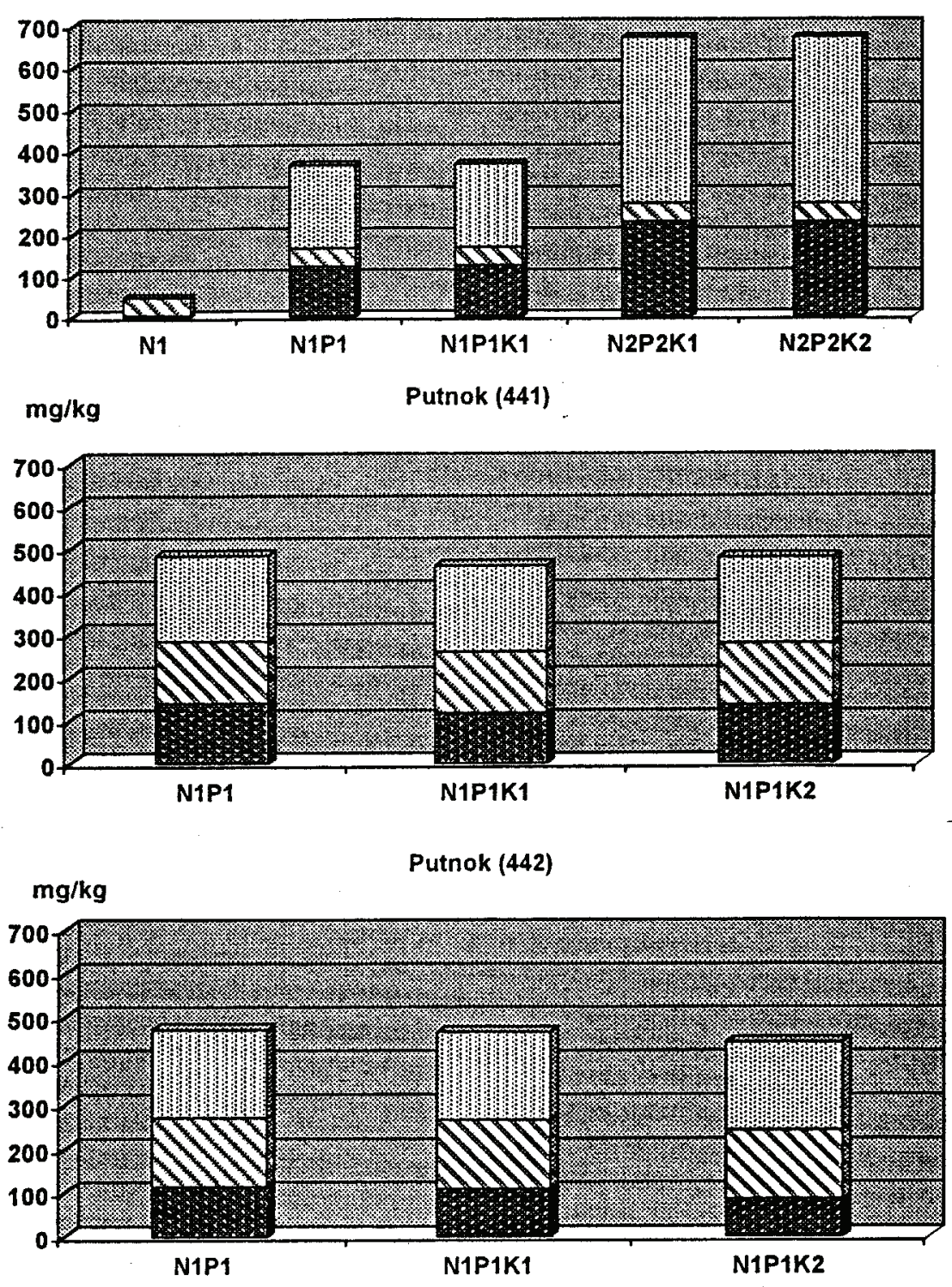

Szolg.ill.adszorpció @ Kiind.AL-P2O5 GHozzáadott

\section{9. ábra}

A putnoki (PU) talaj P-szolgáltatása, ill. -adszorpciója $\left(\mathrm{mg} \mathrm{P}_{2} \mathrm{O}_{5} / \mathrm{kg}\right)$

a)-c, A-C: lásd 1. ábra 


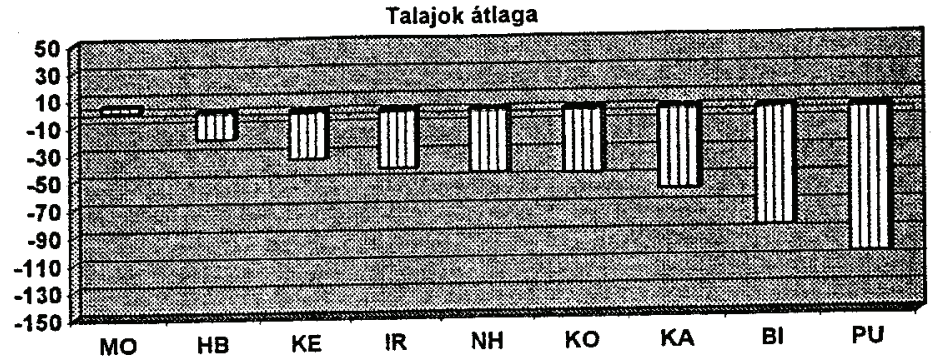

000
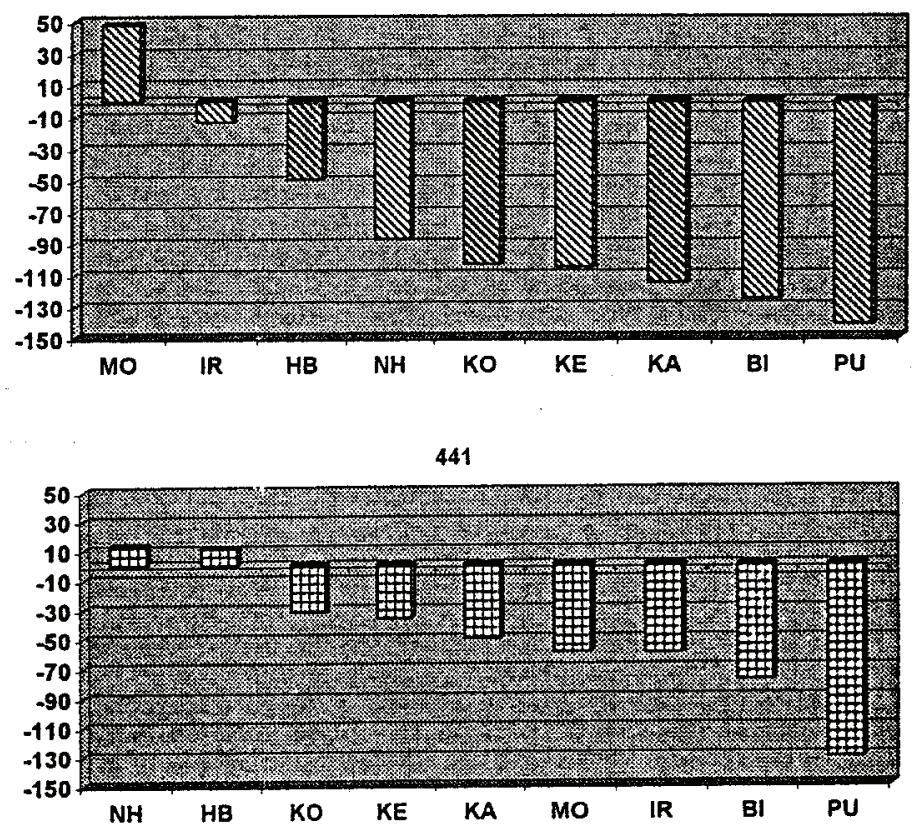

442

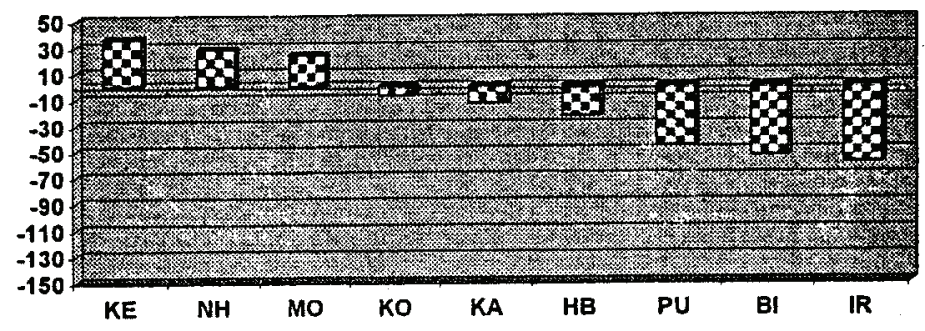

10. ábra

A kísérleti talajok átlagos P-szolgáltatása, ill. -adszorpciója ( $\mathrm{mg}_{2} \mathrm{O}_{5} / \mathrm{kg}$ talaj) A. A talajok értékei az alapkezelések átlagában. B. 000, C. 441, D. 442 alapkezelés 
gosan $+4 \mathrm{mg} \mathrm{P}_{2} \mathrm{O}_{5} / \mathrm{kg}$, tehát nem is mutatkozott adszorpció), a legnagyobb viszont a $\mathrm{PU}$ erősen savanyú talajnál (átlagosan $-106 \mathrm{mg} \mathrm{P}_{2} \mathrm{O}_{5} / \mathrm{kg}$ ).

\section{Következtetések}

A kísérletek során kapott eredmények is igazolják, hogy az egyes talajtípusokon, ill. termőhelyeken szignifikánsan eltérő a P-vegyületek átalakulása. A tartam mütrágyázás hatására módosul a talajok P-szolgáltató képessége, a P-lekötődés viszonyai jelentős eltéréseket mutatnak.

Az összefüggések pontosabb megismerésére indokoltnak tartjuk az általunk végzett kísérletek eredményeinek felhasználásával további elemzések elvégzését, (pl. többlépcsős regressziós analízis stb.) a foszfor lekötődését leginkább meghatározó talajtulajdonságok újabb részleteinek tisztázására .

A talajok P-szolgáltatásának, valamint a P-fixációjának folyamatában érvényesül ugyan a kémhatás, a mészállapot, a szervesanyag-tartalom, továbbá az agyagásványok szerepe, de ezek egyike sem ad önmagában lehetőséget a kérdés teljes magyarázatára. A folyamatok jobb megértéséhez egyaránt szükség van tenyészedény-kísérletek és szabadföldi tartamkísérletek eredményeire.

\section{Összefoglalás}

Tenyészedény-kísérletünkben üvegházi körülmények között, hazánk jellegzetes talajtípusait képviselö talajokon tanulmányoztuk a talaj-növény rendszer P-forgalmát, a 20 éves tartamhatásból származó és a frissen adott P-kezelések hatását a növények szárazanyag-produkciójára, a P-felhalmozásra és egy egyszerűsített mérlegszámítással a talajok P-szolgáltatásának, valamint adszorpciójának sajátosságait (az AL-oldható foszfortartalom alapján).

Megállapítottuk, hogy az egyes talajokon tapasztalt P-szolgáltatás, illetve Plekötődés jelentős különbségeket mutatott. A lekötődés mértéke kapcsolatban volt a talajok kémhatásával, de összefüggött a talajok agyagásványainak menynyiségi és minőségi jellemzőivel is. Azokon a talajokon, ahol nagyobb P-lekötődést tapasztaltunk, a magasabb kaolinit- és montmorillonit-tartalom is szerepet játszhat. A részletek tisztázására további vizsgálatok szükségesek.

A kapott eredmények is felhívják a figyelmet arra, hogy a talajok P-vegyületeinek átalakulásában szerepet játszó tényezők meglehetősen összetett kölcsönhatások eredményeként jutnak kifejezésre. A kérdés részleteinek megismerésében fontos szerepet kapnak a tenyészedény-kísérletek, melyekben megbízható, számszerủ adatok nyerhetők a talaj-növény rendszer P tápelemforgalmára vonatkozóan. Az egyes talajtípusokat leginkább jellemző talajtulajdonságok és a növény P-felhalmozása, valamint a talajban levő és a kijuttatott $\mathrm{P}$ tápanyagmennyiségek közötti kapcsolatok tisztázása ugyancsak hozzájárul a problémák jobb megértéséhez. 
Jelen munka az OTKA támogatásával folyt a T 029355 kutatási pályázat keretében.

\section{Irodalom}

BARROW, N. J. 1980. Evaluation and utilization of residual phosphorus in soils. In: The Role of Phosphorus in Agriculture (Eds.: KhaSawneh, F. E., SAMPLE, E. C. \& Kamprath, E. J.) (Chapter 13). 333-359. American Society of Agronomy. Madison, WI.

Chaminade, R. 1960. Experimentation en petit vases de végétation types d' essais pour tester l'efficacité des engrais humiques. Ann. Agron. 2. 121-133.

DeBRECZENI B. \& DEBRECZENI B-NÉ, 1994. Trágyázási kutatások 1960-1990. Akadémiai Kiadó. Budapest.

Galindo, G. G., Olbuin, C. \& Schalscha, E. B., 1971. Phosphate-sorption capacity of clay fractions of soils derived from volcanic ash. Geoderma. 7. 225-232.

MENGEL, K. 1982. Factors of plant nutrient availability relevant to soil testing. Plant and Soil. 64. 129-138.

Prasad, B. \& SinHA, N. P., 1981. Balance sheet of soil phosphorus and potassium as influenced by intensive cropping and fertilizer use. Plant and Soil. 60. 187-193.

Pratt, P. F., Peterson, F. F. \& Holzley, C. S., 1969. Quantitative mineralogy and chemical properties of a few soils from Sao Paulo, Brazil. Turrialba. 19.491-496.

SÁRDI K., 1993. A talaj-növény rendszer káliumdinamikájának tanulmányozása tenyészedény-kísérletekben. Kandidátusi értekezés. Keszthely.

SÁRDI, K. \& DEBRECZENI, K., 1998. Potassium supplying capacity of soils in long-term fertilization trials studied in a pot experiment. Agrokémia és Talajtan. 47. 165172.

Wilkinson, S. R., GRUNES, D. L. \& SUMNER, M. E., 2000. Nutrient interactions in soil and plant nutrition. (Section D3). In: Handbook of Soil Science. D-89-D-112. CRC Press. Boca Raton-London-New York-Washington

Érkezett: 2001. február 15. 


\title{
Studies on the Phosphorus Adsorption and Supplying Capacity of Soils in Pot Experiments
}

\author{
K. SÁRDI \\ Georgikon Faculty of Agricultural Sciences, Veszprém University, Keszthely
}

\begin{abstract}
Summary
Pot experiments were carried out with perennial ryegrass under greenhouse conditions on representative Hungarian soil types originating from selected treatments on nine sites of the National Long-Term Fertilization Trials in order to study the $\mathrm{P}$ cycle in the soil-plant system, the effect of fresh P treatments and the cumulative effects of 20 years of $\mathrm{P}$ treatment on the dry matter production and $\mathrm{P}$ accumulation of the plants, and the P-supplying and adsorption properties of the soils, using simplified balance calculations based on the AL(ammonium-lactate)-soluble phosphorus content.

The following conclusions could be drawn:

Considerable differences were observed in the P-supplying capacity and $\mathrm{P}$ adsorption of the soils. The extent of adsorption was correlated not only with the soil $\mathrm{pH}$, but also with the quantity and quality of clay minerals in the soil. The higher $\mathrm{P}$ adsorption observed on some soils could be due to the greater kaolinite and montmorillonite contents. Further studies will be required to clarify this question.

The results indicate that the factors involved in the transformation of $\mathrm{P}$ compounds in the soil are manifested as the result of complex interactions. Pot experiments giving reliable numerical data on the $\mathrm{P}$ nutrient cycle in the soil-plant system will be an important part of this work. The clarification of the relationship between the soil properties characteristic of various soil types, the $\mathrm{P}$ accumulation in the plants and the quantities of $\mathrm{P}$ present in the soil or applied as fertiliser will also contribute to the better understanding of the problem.

Table 1. Main agrochemical characteristics and AL-soluble phosphorus content (AL- $\mathrm{P}_{2} \mathrm{O}_{5} \mathrm{mg} / \mathrm{kg}$ ) of soils in selected treatments of the National Long-Term Fertilization Trials. (1) Experimental site. (2) Upper limit of plasticity according to Arany.

Table 2. Dry matter production of perennial ryegrass in pot experiments using soil from the experimental sites of the National Long-Term Fertilization Trials (g/pot). (1) Experimental site. A. 000 basic treatment. B. 441 basic treatment. C. 442 basic treatment.

Table 3. Average quantities of phosphorus taken up by perennial ryegrass in the pot experiments (mg $\mathrm{P}_{2} \mathrm{O}_{5} /$ pot). (1) Experimental site. A. 000 basic treatment. B. 441 basic treatment. C. 442 basic treatment.

Table 4. AL-soluble $\mathrm{P}_{2} \mathrm{O}_{5}$ content $(\mathrm{mg} / \mathrm{kg})$ of the soils at the end of the experiment (mg $\mathrm{P}_{2} \mathrm{O}_{5} /$ pot). (1) Experimental site. A. 000 basic treatment. B. 441 basic treatment. C. 442 basic treatment.
\end{abstract}

Fig 1. Phosphorus-supplying or adsorption characteristics of the Mosonmagyaróvár soil (mg $\mathrm{P}_{2} \mathrm{O}_{5}$ per kg). a) P-supplying capacity or adsorption, b) initial $\mathrm{AL}-\mathrm{P}_{2} \mathrm{O}_{5}, \mathrm{c}$ ) P 
added in the treatments. A. 000 basic treatment. B. 441 basic treatment. C. 442 basic treatment.

Fig 2. Phosphorus-supplying or adsorption characteristics of the Iregszemcse soil ( $\mathrm{mg} \mathrm{P}_{2} \mathrm{O}_{5}$ per kg). Legend: See Fig. 1.

Fig 3. Phosphorus-supplying or adsorption characteristics of the Hajdúböszörmény soil (mg $\mathrm{P}_{2} \mathrm{O}_{5}$ per kg). Legend: See Fig. 1.

Fig 4. Phosphorus-supplying or adsorption characteristics of the Nagyhörcsök soil ( $\mathrm{mg} \mathrm{P}_{2} \mathrm{O}_{5}$ per kg). Legend: See Fig. 1.

Fig 5. Phosphorus-supplying or adsorption characteristics of the Kompolt soil (mg $\mathrm{P}_{2} \mathrm{O}_{5}$ per kg). Legend: See Fig. 1.

Fig 6. Phosphorus-supplying or adsorption characteristics of the Keszthely soil (mg $\mathrm{P}_{2} \mathrm{O}_{5}$ per kg). Legend: See Fig. 1.

Fig 7. Phosphorus-supplying or adsorption characteristics of the Karcag soil (mg $\mathrm{P}_{2} \mathrm{O}_{5}$ per kg). Legend: See Fig. 1.

Fig 8. Phosphorus-supplying or adsorption characteristics of the Bicsérd soil (mg $\mathrm{P}_{2} \mathrm{O}_{5}$ per kg). Legend: See Fig. 1.

Fig 9. Phosphorus-supplying or adsorption characteristics of the Putnok soil (mg $\mathrm{P}_{2} \mathrm{O}_{5}$ per kg). Legend: See Fig. 1.

Fig. 10. Average phosphorus-supplying or adsorption characteristics of the experimental soils $\left(\mathrm{P}_{2} \mathrm{O}_{5} \mathrm{mg}\right.$ per $\mathrm{kg}$ soil $)$. A. Soil values averaged over the basic treatments. B. 000 basic treatment. C. 441 basic treatment. D. 442 basic treatment. 